\title{
Thrombocytopenia: is it a prognostic factor for development of post-hemorrhagic hydrocephalus in neonates?
}

\author{
Ahmed El Damaty ${ }^{1}$ (1) $\cdot$ Luca Giannoni $^{1} \cdot$ Andreas Unterberg $^{1} \cdot$ Heidi Baechli ${ }^{1}$
}

Received: 9 June 2020 / Accepted: 2 July 2020 / Published online: 13 July 2020

(C) The Author(s) 2020

\begin{abstract}
Purpose Post-hemorrhagic hydrocephalus (PHH) is a rare but serious complication among premature babies in the neonatal intensive care unit. The causes of PHH are still not entirely understood, and its prevention and treatment are controversial. We tried to analyze the risk factors for such complication in our cohort.

Methods We reviewed our neonatology data bank and included all preterms below 28 weeks who were born in the period between 1999 and 2014 and suffered from an intraventricular hemorrhage (IVH). We reviewed gestational age, gender, birth weight, type of birth, IVH degree, comorbidities, therapy, complications, time to event, protein content of cerebrospinal fluid, and clinical follow-up.

Results We identified 180 patients, divided into two subgroups, "B1" with 37 cases (IVH + PHH) and "B2" with 143 cases (IVH - PHH). In group B1, the presence of IVH grades I, II, III, or IV was in 11\%, 19\%, and 70\% respectively. Nineteen patients were treated with a ventricular access device (VAD) or external ventricular drain (EVD). A total of 20 shunts were implanted, with 11 revisions (55\%). One patient suffered from thrombocytopenia. In subgroup B2, 51\% showed IVH grade I, whereas severe IVH grades were only present in $22 \% .25 .9 \%$ suffered from thrombocytopenia. Thrombocytopenia was significantly higher in patients who did not develop PHH ( $p$ value: 0.002 ).

Conclusion According to our results, thrombocytopenia could play a decisive role in avoiding development of PHH as a sequel of IVH. We recommend a randomized controlled trial to assess the possible efficacy of antiplatelet drugs in avoiding PHH in this vulnerable group.
\end{abstract}

Keywords Germinal matrix $\cdot$ Hydrocephalus communicans $\cdot$ Intraventricular hemorrhage

\section{Introduction}

Despite the enormous development of treatment options and an increase in prenatal diagnostic procedures, intraventricular hemorrhage (IVH) remains one of the most common complications in premature births [1]. Post-hemorrhagic hydrocephalus (PHH) can develop after IVH due to obliteration of the arachnoid villi by microthrombi with subsequent inflammation and gliosis causing cerebrospinal fluid (CSF) outflow obstruction [2]. The incidence of IVH has decreased steadily

Ahmed El Damaty

ahmed.eldamaty@med.uni-heidelberg.de

1 Department of Neurosurgery, Heidelberg University Hospital, Heidelberg, Germany in the last years [3-6]. However, the risk of developing IVH increases due to steadily improved medical care and intensive therapy; these advancements enabled premature babies to survive with a gestational age below the 28th week of pregnancy [7].

Premature babies are at increased risk of numerous comorbidities [8]. The general definition of prematurity includes all births before the end of the 37th week of gestation [9]. Preterms below the 28th week of pregnancy are called "extremely preterm" [10]. This particular age group develops intraventricular bleeding with a probability of $15-20 \%$ [11]. Although a downward trend in the incidence of IVH has been described in recent decades [12], the incidence of PHH requiring treatment appears to remain constant and is described with a probability of $25-50 \%$ [13]. Despite this fact, unfortunately, no clear guidelines for the treatment of PHH until now have been described, even an optimal time for performing surgical measures is still debatable, and despite adequate therapeutic 
measures, the occurrence of neurological sequelae still occur $[1,12]$.

The aim of this work is to identify the risk factors for the development of PHH in extreme preterms with IVH, as well as the evaluation of the therapies.

\section{Patients and methods}

The study was approved by the local ethics committee. According to this approval, patient consent was not necessary because of the retrospective nature of the study. We did a retrospective review of our neonatology data bank and included all patients who were born in the period from Jan 1999 to Dec 2014 with a gestational age below 28 weeks and suffered from an IVH of any degree. We excluded from the study group all preterm infants with a gestational age above 28 weeks of gestation and those who were born before the end of the 28th week of gestation but had no IVH. Furthermore, all patients with a follow-up period of less than 1 year were excluded from the study. The following data was collected: date of birth; gestational age; gender; birth weight; type of birth; IVH degree (see Table 1); number of multiple pregnancies (single, twin, triplet); comorbidities (such as respiratory and cardiovascular diseases, thrombocytopenia, and sepsis); therapeutic measures such as external ventricular drain (EVD), ventricular access device (VAD), or ventriculoperitoneal (VP) shunt implantation, complications of treatment, period from first diagnosis of PHH to implantation of a VP shunt (time to event), protein content in CSF before shunt implantation, and follow-up (need for speech therapy, physiotherapy, developmental milestones, etc.). In our patients, we did not do neither lumbar punctures nor ventricular taps due to their possible high risk of injury and/or infection. We restricted our operative temporizing measures only to insertion of VAD or rarely EVD.

In our study, we defined thrombocytopenia when the platelet count is below 150/nl; we differentiated between initial thrombocytopenia which was detected in the first blood sample coinciding with the development of intraventricular hemorrhage and transitional or secondary one which appeared

Table 1 Classification of intracranial hemorrhage in premature infants [14]

\begin{tabular}{ll}
\hline IVH grade & Description \\
\hline Grade I & Bleeding is subependymal \\
Grade II & Bleeding is intraventricular without ventricular dilation \\
Grade III & Bleeding is intraventricular with ventricular dilation \\
Grade IV & Bleeding is intraventricular and intraparenchymal \\
\hline
\end{tabular}

with diagnoses associated with abnormal platelet counts, for example pregnancy-induced hypertension, infection, or necrotizing enterocolitis. Platelet transfusion consisted of $10 \mathrm{ml} /$ $\mathrm{kg}$ (neonate's weight at the time of transfusion) of unmodified platelet concentrate and resulted in an average increment of approximately $100 / \mathrm{nl}$. This was performed whenever the platelet count falls below 100/nl, and signs of bleeding tendency or high risk of bleeding were noticed or in case of preoperative preparation.

All patients of the study, as they were extreme premature, received hydrocortison, phenobarbitone, vitamin K, surfactant, antibiotics, and inotropes whenever needed and were intubated and artificially ventilated until the lungs mature, and they could be weaned of the ventilator.

We divided our cohort into 2 groups: study group B including preterm infants who developed IVH and a matched control group K. Group B was subdivided into 2 subgroups: B1 including patients who suffered from IVH and developed $\mathrm{PHH}$ and B2 who suffered from IVH but did not develop PHH. All data were encrypted in self-created database in EXCEL and evaluated with the statistical programs SPSS (version 24) and EXCEL (office version 2010). The relationship between the large study group "B" and the control group " $\mathrm{K}$ " was considered. The control group consisted of patients who were born during the same period with a gestational age under the 28th week of pregnancy but had no IVH. The descriptive analysis was created using the mean, standard deviation, and frequency distributions of various parameters. Different tests were used to check for any existing significance between the two main or the two subgroups. The $t$ test of independent samples was used for all continuous data. The Pearson chi-square test was performed for all nominal and ordinal data. The significance level was $p<0.05$ for all tests.

\section{Results}

The study group "B" included 180 patients and the control group " $K$ " included 101 patients. Furthermore, the study subgroup "B1" included 37 cases (patients with IVH and development of a PHH requiring therapy) and subgroup "B2" included 143 cases (patients with IVH, but without development of PHH); see Fig. 1. For both subgroups, there was a followup interval from a minimum of 1 to 15 years.

\section{Patients' epidemiology}

Study subgroup B1 $(\mathrm{IVH}+\mathrm{PHH})$ which comprised 37 patients showed an average gestational age of 25 weeks +3 days (youngest 22 weeks +6 days and the most mature 27 weeks + 6 days). The average birth weight was $0.785 \mathrm{~kg}$, with a lowest birth weight of just $0.41 \mathrm{~kg}$ and the heaviest of $1.22 \mathrm{~kg}$. Eleven percent of patients in subgroup B1 had an IVH grade I, 19\% 
Fig. 1 Patients' flow chart

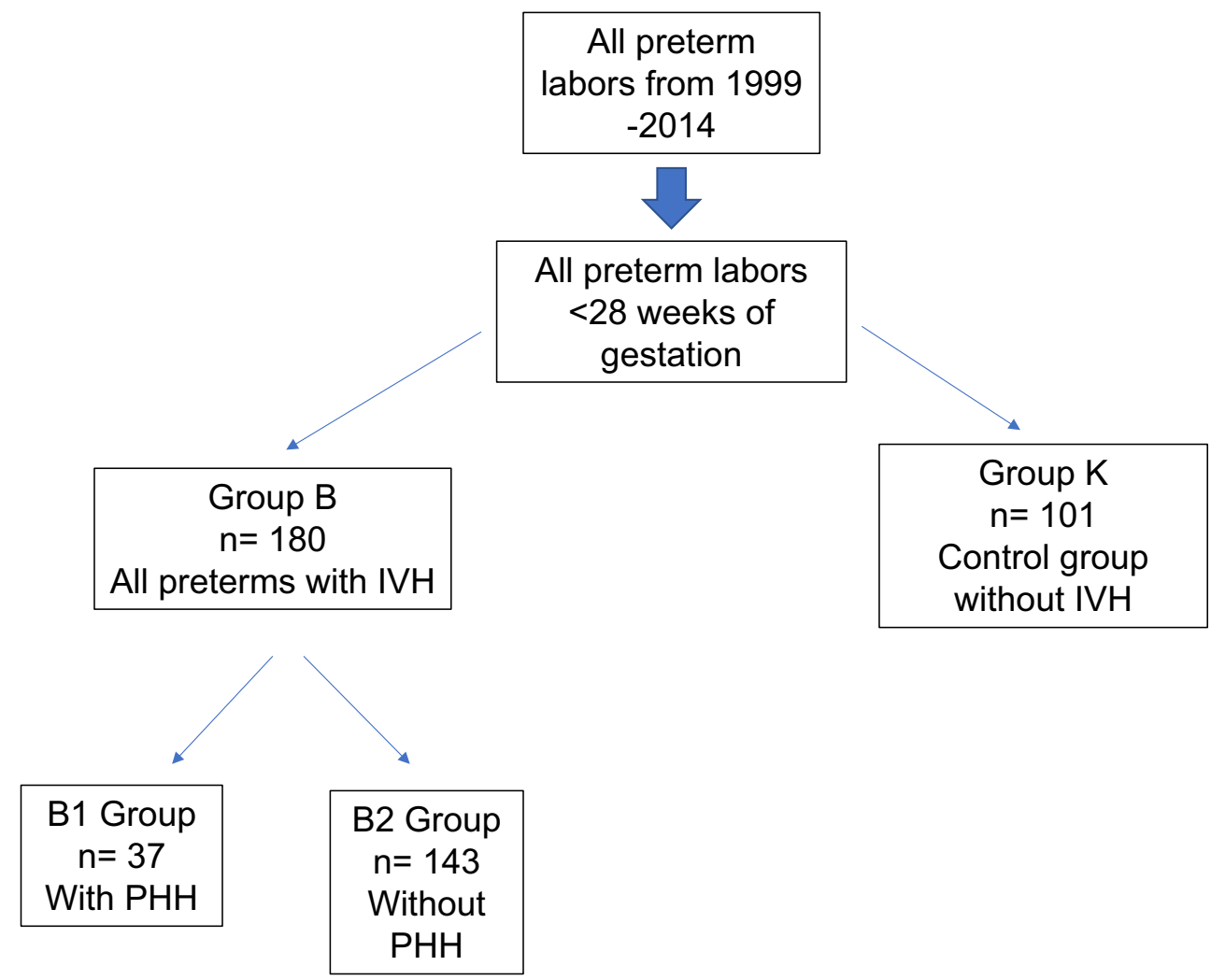

IVH grade II, and a clear majority with $70 \%$ IVH grades III or IV; see Fig. 2. While the gender ratio in bleeding grades I and II seemed to be balanced, intraventricular hemorrhage III-IV grades showed significantly a male predominance of $69 \%$. Nineteen patients were treated with a VAD or EVD, and a total of 20 shunts were implanted, with 11 revisions $(55 \%)$. Unfortunately, 10 patients $(27 \%)$ died. There were $12(32.4 \%)$ multiple pregnancies; see Table 2 for details.

Subgroup B2 consisted of a total of 143 premature babies, all with IVH, but without PHH. The average age was also 25 weeks +3 days (youngest 24 weeks +5 days and the oldest 27 weeks +6 days). The average weight was $0.748 \mathrm{~kg}$. The majority of patients showed $51 \%$ grade I bleeding, whereas severe IVH grade III was only represented with $22 \%$; see Fig. 2 . The gender ratio of subgroup B2 was relatively balanced with $55.9 \%$ male and $44.1 \%$ female children. Of the 143 patients, $31(22 \%)$ died. Twenty-eight percent of the cases were multiple pregnancies.

The control group $\mathrm{K}$ included 101 patients, and they were matched according to gestational age and birth weight. They showed similar averages in these categories as the examination group B. The gender ratio seems very balanced with $55.4 \%$ male and $44.6 \%$ female premature babies. There were almost one quarter of multiple pregnancies, and $10.9 \%$ of pretreatment controls died.

\section{Comorbidities in subgroups}

In subgroup B1, almost half (45.9\%) of the patients had blood pressure fluctuations and almost all $(91.9 \%)$ had respiratory or
Fig. 2 a Group B1 pie chart. b Group B2 pie chart

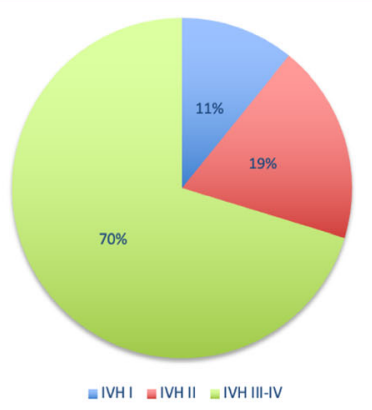

a

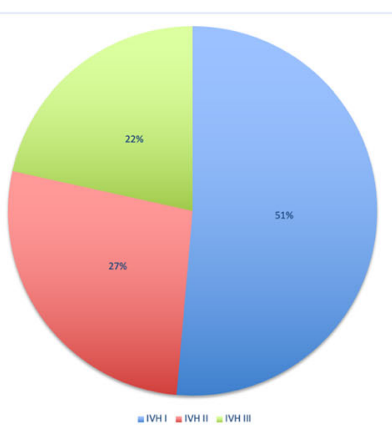

b 
Table 2 Group B1 findings

\begin{tabular}{|c|c|c|c|c|c|c|c|c|c|}
\hline & Age & Birth weight (kg) & $\begin{array}{l}\text { C- } \\
\text { Section }\end{array}$ & Male (\%) & Female $(\%)$ & $\begin{array}{l}\text { VAD/ } \\
\text { EVD }\end{array}$ & Shunt & Revision & Mortality \\
\hline IVH I & $25+2$ & 0.836 & 3 & 50 & 50 & 1 & 1 & 0 & $2(50 \%)$ \\
\hline IVH II & $26+3$ & 0.941 & 5 & 57 & 43 & 4 & 3 & 3 & $0(0 \%)$ \\
\hline IVH III-IV & $25+3$ & 0.735 & 16 & 69 & 31 & 14 & 16 & 8 & $8(31 \%)$ \\
\hline Total & $25+3$ & 0.785 & 24 & 24 & 13 & 19 & 20 & 11 & $10(27 \%)$ \\
\hline
\end{tabular}

cardiovascular diseases. All premature infants with IVH grades I and II had demonstrable respiratory disease. In contrast, premature babies with an IVH grades III or IV only had $89 \%$. In the aspect of cardiovascular diseases, the increase in the grade of bleeding denoted rather a decline in the occurrence of such coincidence, with only $54 \%$ of all patients with IVH grades III-IV having a cardiovascular disease. Twentytwo $(59.5 \%)$ premature babies suffered from sepsis but only 1 patient in this group with IVH grade II initially from thrombocytopenia $(2.7 \%)$.

Subgroup B2 initially showed a similar trend in terms of comorbidities. Both the presence of respiratory and cardiovascular diseases decreases as the severity of intraventricular hemorrhage increases. $71.3 \%$ showed blood pressure fluctuations, and even $97.9 \%$ of the children had respiratory and cardiovascular diseases. Nearly three quarters $(71.3 \%)$ of premature babies suffered from sepsis, and regarding the initial thrombocytopenia, we noticed a slight increase in incidence with higher IVH grades: in grade I, thrombocytopenia was in $23 \%, 28 \%$ in grade II, and $29 \%$ in grades III and IV, with a total percentage of $25.9 \%$. When we collectively reviewed our study group B, we found most of the patients suffered from respiratory and/or cardiovascular problems which are very frequent in extreme preterms; see Fig. 3.

In the control group $\mathrm{K}$, in $48.5 \%$, they showed blood pressure fluctuations and all of them had a respiratory or cardiovascular disease without exception. In $68.3 \%$ of patients, they suffered from sepsis; only $11.9 \%$ had initial thrombocytopenia.

\section{Thrombocytopenia}

First, the large study group B with a total of 180 patients was compared with the control group $\mathrm{K}$ with 101 patients. The presence of initial thrombocytopenia in the patients of study group B is higher in comparison with the "healthy" preterms of control group $\mathrm{K} ; 21.1 \%$ versus $11.9 \%$ ( $p$ value 0.052 ); see Table 3. Additionally, we found in terms of blood pressure fluctuations statistical significance ( $p$ value of 0.004 ) and in mortalities ( $p$ value of 0.023 ). Here, it was shown that patients with IVH have significantly more blood pressure fluctuations and, above all, increased mortality.
In the second step, subgroup B1 which included 37 patients were compared with the subgroup B2 including 143 patients. We found that more premature babies of subgroup B2 exhibited initial thrombocytopenia and it was barely present in the patients of subgroup B1 ( $p$ value 0.002 ); see Table 4. Also, the IVH grade showed strong significance ( $p$ value $<0.00001$ ) in terms of developing PHH requiring therapy. Regarding the blood pressure fluctuations, we observed that the premature babies of subgroup B2 had much more frequent blood pressure fluctuations ( $p$ value 0.004 ).

\section{Discussion}

\section{Management of PHH}

The initial therapy of a diagnosed IVH aims to prevent further damage to the brain tissue through maintaining cerebral perfusion. The treatment of $\mathrm{PHH}$ in premature babies has been changed markedly in the last years [15]. A common consensus nowadays is to temporarily alleviate the pressure with an EVD or the implantation of a Rickham reservoir as a VAD until the necessity and feasibility of implantation of a VP shunt is decided [16]. Another study was devoted to neuroendoscopic lavage, which is proven to be helpful in newborns by breaking down the hematoma and washing out the residual bleeding; the initial evaluations showed a significantly lower shunt rate in the treated patients [17].

Lekic et al. [18] stated that early implantation of a VP shunt for the treatment of PHH is the method of choice. However, the VP shunt implantation can also bring many complications. Therefore, a non-invasive solution avoiding a shunt implantation would be desirable and could improve the quality of life of these patients [19]. A prospective multicenter study (TROPHY Register) deals specifically with the therapeutic measures of PHH and tries to establish clear guidelines and therapy recommendations for the treatment [20]. However, further clinical observation and evaluation are required.

\section{Grade of IVH, birth weight, and development of PHH}

Previous studies showed that the more immaturity of a newborn, the higher the mortality rate $[2,12,13]$. Ten to fifteen 


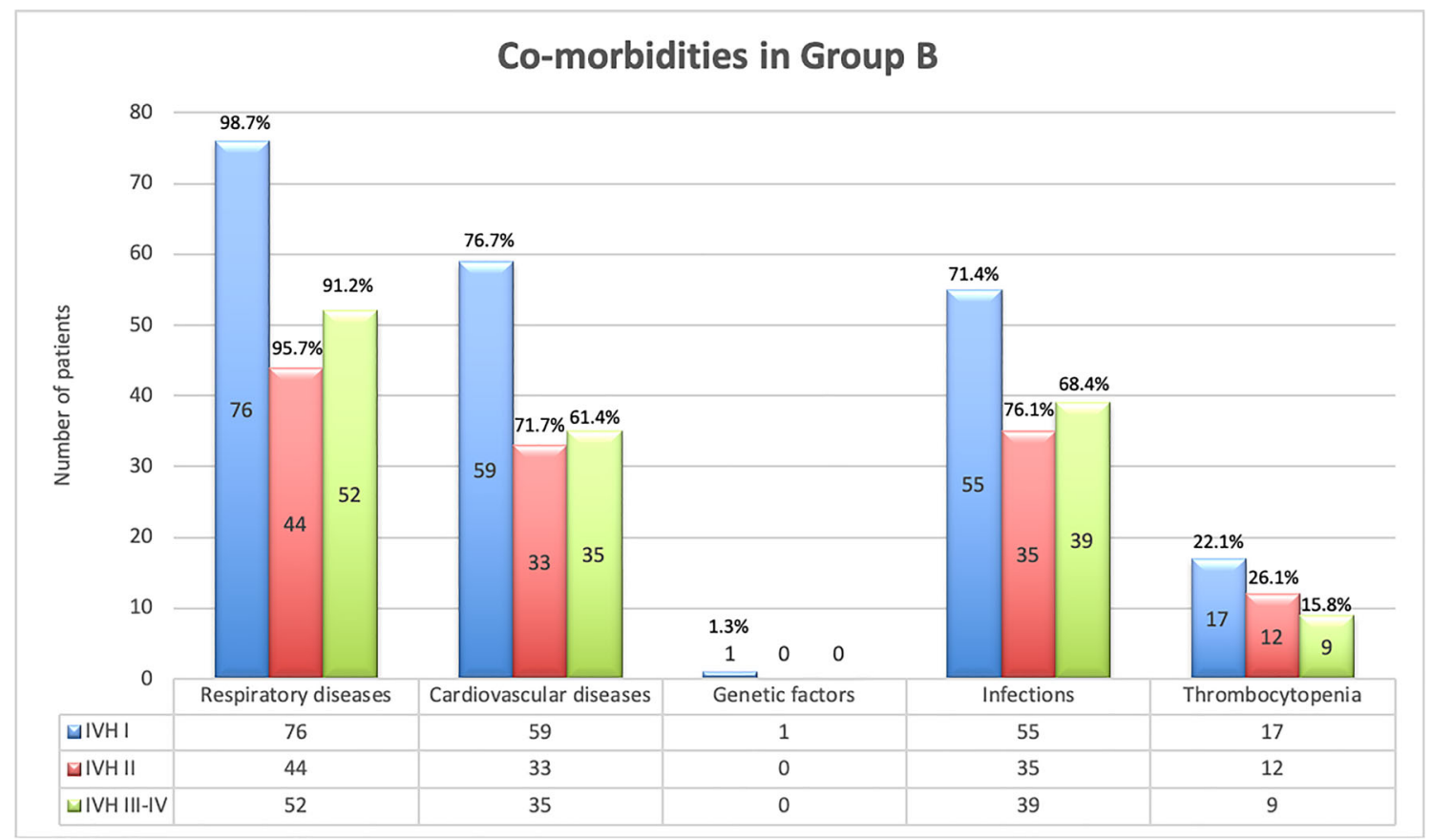

Fig. 3 Comorbidities in group B

percent of premature babies weighing less than $1500 \mathrm{~g}$ develop IVH and up to a third of them develop PHH [21]. The severity or extent of the germinal matrix bleeding correlates directly with the mortality of the premature babies; in premature infants with an IVH grade I, the death rate is only $10 \%$, but with the severe grades III and IV, death rate is already at $26 \%$ and $47 \%$, respectively [22]. Our study examined 180 patients, 37 of whom developed PHH representing

Table 3 Statistical overview comparing results of groups B and K

\begin{tabular}{|c|c|c|c|}
\hline & Group B $(n=180)$ & Group K $(n=101)$ & $p$ value \\
\hline Gestational age in days & $178.2 \pm 10.64$ & $178.7 \pm 10.39$ & 0.685 \\
\hline Weight in $\mathrm{kg}$ & $0.756 \pm 0.209$ & $0.751 \pm 0.212$ & 0.856 \\
\hline Gender (m/f) & $\begin{array}{l}\mathrm{m}=104(57.8 \%) \\
\mathrm{f}=76(42.2 \%)\end{array}$ & $\begin{array}{l}\mathrm{m}=56(55.4 \%) \\
\mathrm{f}=45(44.6 \%)\end{array}$ & 0.705 \\
\hline Type of delivery (Cesarean section/normal) & $\mathrm{CS}=137(76.1 \%)$ Normal $=43(23.9 \%)$ & $\begin{array}{l}\mathrm{CS}=78(77.2 \%) \\
\text { Normal }=23(22.8 \%)\end{array}$ & 0.832 \\
\hline IVH grade (I-IV) & $\begin{array}{l}\mathrm{I}=77(42.8 \%) \\
\mathrm{II}=46(25.6 \%) \\
\mathrm{III}=52(28.9 \%) \\
\mathrm{IV}=5(2.8 \%)\end{array}$ & 1 & $\mathrm{n} / \mathrm{a}$ \\
\hline Multiple pregnancy (yes/no) & $\begin{array}{l}\mathrm{y}=52(28.9 \%) \\
\mathrm{n}=128(71.1 \%)\end{array}$ & $\begin{array}{l}\mathrm{y}=25(24.8 \%) \\
\mathrm{n}=76(75.2 \%)\end{array}$ & 0.456 \\
\hline Blood pressure variations (yes/no) & $\begin{array}{l}\mathrm{y}=119(66.1 \%) \\
\mathrm{n}=61(33.9 \%)\end{array}$ & $\begin{array}{l}\mathrm{y}=49(48.5 \%) \\
\mathrm{n}=52(51.5 \%)\end{array}$ & 0.004 \\
\hline Respiratory-cardiovascular diseases (yes/no) & $\begin{array}{l}\mathrm{y}=174(96.7 \%) \\
\mathrm{n}=6(3.3 \%)\end{array}$ & $\begin{array}{l}\mathrm{y}=101(100 \%) \\
\mathrm{n}=0(0 \%)\end{array}$ & 0.064 \\
\hline Blood transfusion (yes/no) & $\begin{array}{l}\mathrm{y}=15(8.3 \%) \\
\mathrm{n}=165(91.7 \%)\end{array}$ & $\begin{array}{l}\mathrm{y}=4(4 \%) \\
\mathrm{n}=97(96 \%)\end{array}$ & 0.161 \\
\hline Sepsis/infection (yes/no) & $\begin{array}{l}\mathrm{y}=124(68.9 \%) \\
\mathrm{n}=56(31.1 \%)\end{array}$ & $\begin{array}{l}\mathrm{y}=69(68.3 \%) \\
\mathrm{n}=32(31.7 \%)\end{array}$ & 0.921 \\
\hline Thrombocytopenia (yes/no) & $\begin{array}{l}\mathrm{y}=38(21.1 \%) \\
\mathrm{n}=142(78.9 \%)\end{array}$ & $\begin{array}{l}\mathrm{y}=12(11.9 \%) \\
\mathrm{n}=89(88.1 \%)\end{array}$ & 0.052 \\
\hline Mortality (yes/no) & $\begin{array}{l}\mathrm{y}=39(21.7 \%) \\
\mathrm{n}=141(78.3 \%)\end{array}$ & $\begin{array}{l}\mathrm{y}=11(10.9 \%) \\
\mathrm{n}=90(89.1 \%)\end{array}$ & 0.023 \\
\hline
\end{tabular}

Blood pressure variations were significantly higher in patients with IVH in comparison to control group ( $p$ value 0.004$)$. Also mortality was significantly higher in patients with IVH ( $p$ value 0.023 ) 
Table 4 Statistical overview comparing results of groups B1 and B2

\begin{tabular}{|c|c|c|c|}
\hline & Group B1 $(n=37)$ & Group B2 $(n=143)$ & $p$ value \\
\hline Gestational age in days & $180.4 \pm 10.13$ & $177.6 \pm 10.72$ & 0.153 \\
\hline Weight in $\mathrm{kg}$ & $0.785 \pm 0.205$ & $0.748 \pm 0.211$ & 0.348 \\
\hline Gender $(\mathrm{m} / \mathrm{f})$ & $\begin{array}{l}\mathrm{m}=24(64.9 \%) \\
\mathrm{f}=13(35.1 \%)\end{array}$ & $\begin{array}{l}\mathrm{m}=80(55.9 \%) \\
\mathrm{f}=63(44.1 \%)\end{array}$ & 0.327 \\
\hline Type of delivery (Cesarean section/normal) & $\mathrm{CS}=24(64.9 \%)$ Normal $=13(35.1 \%)$ & $\begin{array}{l}\mathrm{CS}=113(79 \%) \\
\text { Normal }=30(21 \%)\end{array}$ & 0.072 \\
\hline IVH grade (I-IV) & $\begin{array}{l}\mathrm{I}=4(10.8 \%) \\
\mathrm{II}=7(18.9 \%) \\
\mathrm{III}=22(59.5 \%) \\
\mathrm{IV}=4(10.8 \%)\end{array}$ & $\begin{array}{l}\mathrm{I}=73(51 \%) \\
\mathrm{II}=39(27.3 \%) \\
\mathrm{III}=30(21 \%) \\
\mathrm{IV}=1(0.7 \%)\end{array}$ & $<0.0001$ \\
\hline Multiple pregnancy (yes/no) & $\begin{array}{l}\mathrm{y}=12(32.4 \%) \\
\mathrm{n}=25(67.6 \%)\end{array}$ & $\begin{array}{l}\mathrm{y}=40(28 \%) \\
\mathrm{n}=103(72 \%)\end{array}$ & 0.594 \\
\hline Blood pressure variations (yes/no) & $\begin{array}{l}\mathrm{y}=17(45.9 \%) \\
\mathrm{n}=20(54.1 \%)\end{array}$ & $\begin{array}{l}\mathrm{y}=102(71.3 \%) \\
\mathrm{n}=41(28.7 \%)\end{array}$ & 0.004 \\
\hline Respiratory-cardiovascular diseases (yes/no) & $\begin{array}{l}\mathrm{y}=34(91.9 \%) \\
\mathrm{n}=3(8.1 \%)\end{array}$ & $\begin{array}{l}\mathrm{y}=140(97.9 \%) \\
\mathrm{n}=3(2.1 \%)\end{array}$ & 0.069 \\
\hline Blood transfusion (yes/no) & $\begin{array}{l}y=6(16.2 \%) \\
n=31(83.8 \%)\end{array}$ & $\begin{array}{l}\mathrm{y}=9(6.3 \%) \\
\mathrm{n}=134(93.7 \%)\end{array}$ & 0.052 \\
\hline Sepsis/infection (yes/no) & $\begin{array}{l}\mathrm{y}=22(59.5 \%) \\
\mathrm{n}=15(40.5 \%)\end{array}$ & $\begin{array}{l}\mathrm{y}=102(71.3 \%) \\
\mathrm{n}=41(28.7 \%)\end{array}$ & 0.165 \\
\hline Shunt implantation (yes/no) & $\begin{array}{l}\mathrm{y}=20(54.1 \%) \\
\mathrm{n}=17(45.9 \%)\end{array}$ & 1 & $\mathrm{n} / \mathrm{a}$ \\
\hline Rickham reservoir (yes/no) & $\begin{array}{l}\mathrm{y}=19(51.4 \%) \\
\mathrm{n}=18(48.6 \%)\end{array}$ & l & $\mathrm{n} / \mathrm{a}$ \\
\hline Revisions (yes/no) & $\begin{array}{l}\mathrm{y}=17(45.9 \%) \\
\mathrm{n}=20(54.1 \%)\end{array}$ & / & $\mathrm{n} / \mathrm{a}$ \\
\hline Hydrocephalus (yes/no) & $\begin{array}{l}\mathrm{y}=37(100 \%) \\
\mathrm{n}=0(0 \%)\end{array}$ & l & $\mathrm{n} / \mathrm{a}$ \\
\hline Thrombocytopenia (yes/no) & $\begin{array}{l}\mathrm{y}=1(2.7 \%) \\
\mathrm{n}=36(97.3 \%)\end{array}$ & $\begin{array}{l}\mathrm{y}=37(25.9 \%) \\
\mathrm{n}=106(74.1 \%)\end{array}$ & 0.002 \\
\hline Mortality (yes/no) & $\begin{array}{l}\mathrm{y}=10(27 \%) \\
\mathrm{n}=27(73 \%)\end{array}$ & $\begin{array}{l}\mathrm{y}=29(20.3 \%) \\
\mathrm{n}=114(79.7 \%)\end{array}$ & 0.375 \\
\hline
\end{tabular}

Thrombocytopenia was significantly higher in patients who developed IVH but did not proceed to PHH ( $p$ value 0.002 )

around $20 \%$. Twenty-six (70\%) of these premature babies suffered from IVH grade III or IV. From the 143 patients who did not develop hydrocephalus, 73 patients (51\%) suffered from IVH grade I. This clearly shows that the incidence of developing PHH increases drastically with the immaturity of the premature babies and especially the severity of the IVH.

\section{Correlation between thrombocytopenia and the development of PHH}

Póvoa et al. [23] reported that fetal/neonatal alloimmune thrombocytopenia is one of the most common causes of severe thrombocytopenia in the newborn. It results from fetomaternal mismatch for human platelet alloantigens leading to antibody-mediated destruction of fetal platelets. In severe cases, intracranial hemorrhage may occur and lead to death or neurologic sequelae. On the contrary, Bu et al. [24] explained in adults the development of PHH as a sequel of IVH; they focused on the mechanisms of hydrocephalus after adult IVH, including blood clot blockage, barrier impairment, inflammation, and blood components. Hence, a normal coagulation function is needed to develop the full-blown picture of PHH. Clinically, hematoma volume after GMH-IVH is a prognostic indicator of future neurologic outcomes [25-27]. Various preclinical models of stroke have shown that rapid hematoma clearance after hemorrhagic stroke ameliorated inflammation and improved neurological deficits in the short and long terms [28]. Rappard et al. [29] found that the blood clot firmness is highly depending on the platelet count and that thrombocytopenia results in a soft unstable clot. Similarly, thrombocytopenia may help in the decrease of clot formation with its sequelae of blockage, barrier impairment, and inflammatory reaction, and even if the intraventricular hematoma is formed it is not firm and usually resorbs faster.

In our cohort, we found that initial thrombocytopenia was detected in more patients who developed IVH (group B) in comparison with the control group (group K) $21.1 \%$ vs $11.9 \%$ ( $p$ value 0.052 ) but statistically not significant. This could be explained either that thrombocytopenia is the cause for IVH through a bleeding tendency or as a sequel through consumption of platelets in forming the blood clot in the ventricular system. Regarding the two 
groups who developed IVH, we found a marked increase in the incidence of thrombocytopenia in the group who did not develop PHH (group B2) in comparison with those who developed PHH (group B1) $25.9 \%$ vs $2.7 \%$ ( $p$ value 0.002 ). This raises the assumption that the platelet count may be crucial in deciding whether, after development of the IVH, the cascade will continue to develop $\mathrm{PHH}$ or the process will be less severe with less damage and less sequelae evading the development of PHH.

TGF- $\beta$ stimulates mesenchymal stem cells and fibroblasts, which produce ECM matrix proteins and deposit connective tissue (Bowen et al. 2013). TGF- $\beta$ can be secreted from activated microglia, and TGF- $\beta$ secretion can be induced by thrombin (Schuliga 2015). ECM production induced by TGF- $\beta$ stimulation may deposit in the cerebroventricular system, disrupting CSF dynamics (Tada, Kanaji, \& Kobayashi, 1994). A rabbit pup GMH model indicated TGF- $\beta$, fibronectin, and laminin expression levels were significantly increased in the ependymal and subependyma tissues after GMH (Cherian, Thoresen, Silver, Whitelaw, \& Love, 2004a). Mice with transgenic TGF- $\beta$ overexpression developed hydrocephalus with higher expression of ECM proteins in the brain than wild types (Wyss-Coray et al., 1995). In a clinical study, increased TGF- $\beta 1$ and ECM protein expression in the CSF were associated with $\mathrm{PHH}$ development in preterm infants (Aquilina, Chakkarapani, \& Thoresen, 2012; DouglasEscobar \& Weiss, 2012). The TGF- $\beta 1$ isoform is mostly associated with PHH after IVH in neonates and adults (Gomes, Sousa Vde, \& Romao, 2005). Intrathecal TGF- $\beta 1$ injection in mice resulted in hydrocephalus development, and TGF- $\beta 1$ expression was significantly increased in brains of neonatal rats with PHVD after intraventricular blood injection (Cherian, Thoresen et al., 2004a; Tada et al., 1994). Indeed, TGF- $\beta 1$ was elevated in both animal models and premature infants with $\mathrm{PHH}$, although some studies dispute this (Heep et al., 2004). In a rat GMH model, TGF- $\beta 1$ was elevated within hours after GMH, but normalized by 24 -h post-ictus (Tang, Chen et al., 2015). Additionally, inhibiting TGF- $\beta 1$ ameliorated long-term $\mathrm{PHH}$ and neurocognitive deficits as well as reduced vitronectin and GFAP expression in rats (Manaenko et al. 2014). Although the mechanism of TGF- $\beta$ signaling after GMH and its association with PHH development has been established, studies are lacking that discern the changes to CSF dynamics as a consequence of TGF- $\beta$ signaling and fibrosis.

Transforming growth factor $\beta 1$ (TGF- $\beta 1$ ) is a plateletderived cytokine involved in both normal wound healing and scarring [30]. TGF- $\beta$ activates mesenchymal stem cells and fibroblasts, to produce extracellular matrix (ECM) proteins and deposit connective tissue [31]. TGF- $\beta$ can be secreted from activated microglia, and its secretion can be induced by thrombin [32]. Monroe et al. [33] showed that platelets play a major role in localizing and controlling the burst of thrombin generation leading to fibrin clot formation. Additionally, the increased level of ECM proteins, induced by TGF- $\beta$ stimulation, may lead to its deposition in the cerebroventricular system and disruption of the CSF dynamics causing hydrocephalus $[19,34]$. Mice with transgenic TGF- $\beta$ overexpression developed hydrocephalus with higher expression of ECM proteins in their brains than wild types [35]. Intrathecal TGF- $\beta 1$ injection in mice resulted in development of hydrocephalus, and TGF- $\beta 1$ expression was significantly higher in brains of neonatal rats with post-hemorrhagic ventricular dilatation after injection of blood intraventricular $[34,36]$. In a clinical study, increased TGF- $\beta 1$ and ECM protein expression in the CSF was associated with PHH development in preterm infants [37, 38]. Additionally, inhibiting TGF- $\beta 1$ minimized the long-term PHH and neurocognitive deficits in germinal matrix hemorrhage $(\mathrm{GMH})$ model in rats [39]. Although the mechanism of TGF- $\beta$ signaling after GMH and its association with PHH development has been established, we are still in short of studies that detect the changes to CSF dynamics as a consequence of TGF- $\beta$ signaling and fibrosis.

To summarize, platelets play a decisive role in fibrin clot formation and to a major extent decide its firmness and stability. Additionally, platelets through mediating TGF- $\beta$ complex play an important role in the development of the astrogliosis disrupting the CSF dynamics intraparenchymally and contributing to the development of PHH. Hence, we hope that through further studies focusing on these information, we could help to minimize the incidence of development of PHH following IVH in neonates.

\section{Conclusion}

According to our results, we found that the grade of intraventricular hemorrhage defines at utmost the incidence of development of post-hemorrhagic hydrocephalus. Also, we found that the incidence of shunt complications is in direct proportion to the initial grade of IVH; although in all patients, irrespective to the IVH grade, the VP shunt was inserted with almost similar protein content in CSF. Finally, we found that thrombocytopenia was significantly higher in patients who developed intraventricular hemorrhage but did not develop post-hemorrhagic hydrocephalus. Hence, thrombocytopenia could play a decisive role in avoiding development of $\mathrm{PHH}$ as a sequel of IVH. We recommend a randomized controlled trial to assess the possible efficacy of antiplatelet drugs in avoiding PHH in this vulnerable group.

Funding information Open Access funding provided by Projekt DEAL.

\section{Compliance with ethical standards}

Conflict of interest None. 
Ethics approval This study was approved by the local ethics committee in our Institute.

Open Access This article is licensed under a Creative Commons Attribution 4.0 International License, which permits use, sharing, adaptation, distribution and reproduction in any medium or format, as long as you give appropriate credit to the original author(s) and the source, provide a link to the Creative Commons licence, and indicate if changes were made. The images or other third party material in this article are included in the article's Creative Commons licence, unless indicated otherwise in a credit line to the material. If material is not included in the article's Creative Commons licence and your intended use is not permitted by statutory regulation or exceeds the permitted use, you will need to obtain permission directly from the copyright holder. To view a copy of this licence, visit http://creativecommons.org/licenses/by/4.0/.

\section{References}

1. Christian EA, Melamed EF, Peck E, Krieger MD, McComb JG (2016) Surgical management of hydrocephalus secondary to intraventricular hemorrhage in the preterm infant. J Neurosurg Pediatr 17:278-284. https://doi.org/10.3171/2015.6.PEDS15132

2. Strahle J, Garton HJL, Maher CO, Muraszko KM, Keep RF, Xi G (2012) Mechanisms of hydrocephalus after neonatal and adult intraventricular hemorrhage. Transl Stroke Res 3:25-38. https:/doi. org/10.1007/s12975-012-0182-9

3. Amato M, Howald H, von Muralt G (1986) Neurological prognosis of high-risk preterm infants with peri-intraventricular hemorrhage and ventricular dilatation. Eur Neurol 25:241-247. https://doi.org/ $10.1159 / 000116015$

4. Kuban K, Sanocka U, Leviton A et al (1999) White matter disorders of prematurity: association with intraventricular hemorrhage and ventriculomegaly. The Developmental Epidemiology Network. J Pediatr 134:539-546. https://doi.org/10.1016/s0022-3476(99) 70237-4

5. Papile LA, Munsick-Bruno G, Schaefer A (1983) Relationship of cerebral intraventricular hemorrhage and early childhood neurologic handicaps. J Pediatr 103:273-277. https://doi.org/10.1016/ s0022-3476(83)80366-7

6. Tsuji M, Saul JP, du Plessis A, Eichenwald E, Sobh J, Crocker R, Volpe JJ (2000) Cerebral intravascular oxygenation correlates with mean arterial pressure in critically ill premature infants. Pediatrics 106:625-632. https://doi.org/10.1542/peds.106.4.625

7. Humberg A, Härtel C, Rausch TK, Stichtenoth G, Jung P, Wieg C, Kribs A, von der Wense A, Weller U, Höhn T, Olbertz DM, Felderhoff-Müser U, Rossi R, Teig N, Heitmann F, Schmidtke S, Bohnhorst B, Vochem M, Segerer H, Möller J, Eichhorn JG, Wintgens J, Böttger R, Hubert M, Dördelmann M, Hillebrand G, Roll C, Jensen R, Zemlin M, Mögel M, Werner C, Schäfer S, Schaible T, Franz A, Heldmann M, Ehlers S, Kannt O, Orlikowsky T, Gerleve H, Schneider K, Haase R, Böckenholt K, Linnemann K, Herting E, Göpel W (2019) Active perinatal care of preterm infants in the German Neonatal Network. Arch Dis Child Fetal Neonatal Ed 105:190-195. https://doi.org/10.1136/ archdischild-2018-316770

8. Eichenwald EC, Stark AR (2008) Management and outcomes of very low birth weight. N Engl J Med 358:1700-1711. https://doi. org/10.1056/NEJMra0707601

9. Blencowe H, Cousens S, Oestergaard MZ, Chou D, Moller AB, Narwal R, Adler A, Vera Garcia C, Rohde S, Say L, Lawn JE (2012) National, regional, and worldwide estimates of preterm birth rates in the year 2010 with time trends since 1990 for selected countries: a systematic analysis and implications. Lancet Lond
Engl 379:2162-2172. https://doi.org/10.1016/S0140-6736(12) 60820-4

10. Moutquin J-M (2003) Classification and heterogeneity of preterm birth. BJOG Int J Obstet Gynaecol 110(Suppl 20):30-33. https:// doi.org/10.1016/s1470-0328(03)00021-1

11. O'Leary H, Gregas MC, Limperopoulos C et al (2009) Elevated cerebral pressure passivity is associated with prematurity-related intracranial hemorrhage. Pediatrics 124:302-309. https://doi.org/ 10.1542/peds.2008-2004

12. Robinson S (2012) Neonatal posthemorrhagic hydrocephalus from prematurity: pathophysiology and current treatment concepts. J Neurosurg Pediatr 9:242-258. https://doi.org/10.3171/2011.12. PEDS11136

13. Limbrick DD, Mathur A, Johnston JM, Munro R, Sagar J, Inder T, Park TS, Leonard JL, Smyth MD (2010) Neurosurgical treatment of progressive posthemorrhagic ventricular dilation in preterm infants: a 10-year single-institution study. J Neurosurg Pediatr 6:224-230. https://doi.org/10.3171/2010.5.PEDS1010

14. Deeg KH, Staudt F, Rohden L v (1999) Klassifikation der intrakraniellen Blutungen des Frühgeborenen. Ultraschall Med 20:165-170. https://doi.org/10.1055/s-1999-8898

15. Badhiwala JH, Hong CJ, Nassiri F, Hong BY, Riva-Cambrin J, Kulkarni AV (2015) Treatment of posthemorrhagic ventricular dilation in preterm infants: a systematic review and meta-analysis of outcomes and complications. J Neurosurg Pediatr 16:545-555. https://doi.org/10.3171/2015.3.PEDS14630

16. Shooman D, Portess H, Sparrow O (2009) A review of the current treatment methods for posthaemorrhagic hydrocephalus of infants. Cerebrospinal Fluid Res 6:1. https://doi.org/10.1186/1743-8454-61

17. Schulz M, Bührer C, Pohl-Schickinger A, Haberl H, Thomale UW (2014) Neuroendoscopic lavage for the treatment of intraventricular hemorrhage and hydrocephalus in neonates: clinical article. J Neurosurg Pediatr 13:626-635

18. Lekic T, Klebe D, Poblete R, Krafft P, Rolland W, Tang J, Zhang J (2015) Neonatal brain hemorrhage $(\mathrm{NBH})$ of prematurity: translational mechanisms of the vascular-neural network. Curr Med Chem 22:1214-1238

19. Klebe D, McBride D, Krafft PR, Flores JJ, Tang J, Zhang JH (2019) Posthemorrhagic hydrocephalus development after germinal matrix hemorrhage: established mechanisms and proposed pathways. J Neurosci Res 98:105-120. https://doi.org/10.1002/jnr.24394

20. Thomale U-W, Cinalli G, Kulkarni AV, al-Hakim S, Roth J, Schaumann A, Bührer C, Cavalheiro S, Sgouros S, Constantini S, Bock HC (2019) TROPHY registry study design: a prospective, international multicenter study for the surgical treatment of posthemorrhagic hydrocephalus in neonates. Childs Nerv Syst 35:613619. https://doi.org/10.1007/s00381-019-04077-4

21. Shah PS, Lui K, Sjörs G et al (2016) Neonatal outcomes of very low birth weight and very preterm neonates: an international comparison. J Pediatr 177:144-152.e6. https://doi.org/10.1016/j.jpeds. 2016.04.083

22. Radic JAE, Vincer M, McNeely PD (2015) Outcomes of intraventricular hemorrhage and posthemorrhagic hydrocephalus in a population-based cohort of very preterm infants born to residents of Nova Scotia from 1993 to 2010. J Neurosurg Pediatr 15:580588. https://doi.org/10.3171/2014.11.PEDS14364

23. Póvoa AM, Ramalho C, Machado AP, Matias A, Montenegro N (2007) Congenital posthemorrhagic hydrocephalus: a case of fetomaternal alloimmune thrombocytopenia. Fetal Diagn Ther 22: 321-324. https://doi.org/10.1159/000103288

24. Bu Y, Chen M, Gao T, Wang X, Li X, Gao F (2016) Mechanisms of hydrocephalus after intraventricular haemorrhage in adults. BMJ 1:23-27. https://doi.org/10.1136/svn-2015-000003

25. Flores JJ, Klebe D, Tang J, Zhang JH (2020) A comprehensive review of therapeutic targets that induce microglia/macrophage- 
mediated hematoma resolution after germinal matrix hemorrhage. $\mathrm{J}$ Neurosci Res 98:121-128. https://doi.org/10.1002/jnr.24388

26. Keep RF, Guohua X, Ya H, Hoff JT (2005) The deleterious or beneficial effects of different agents in intracerebral hemorrhage. Stroke 36:1594-1596. https://doi.org/10.1161/01.STR. 0000170701.41507.e1

27. Xi G, Keep RF, Hoff JT (2006) Mechanisms of brain injury after intracerebral haemorrhage. Lancet Neurol 5:53-63. https://doi.org/ 10.1016/S1474-4422(05)70283-0

28. Zhao X, Sun G, Zhang J, Strong R, Song W, Gonzales N, Grotta JC, Aronowski J (2007) Hematoma resolution as a target for intracerebral hemorrhage treatment: role for peroxisome proliferatoractivated receptor $\gamma$ in microglia/macrophages. Ann Neurol 61: 352-362. https://doi.org/10.1002/ana.21097

29. von Rappard S, Hinnen C, Lussmann R, Rechsteiner M, Korte W (2017) Factor XIII deficiency and thrombocytopenia are frequent modulators of postoperative clot firmness in a surgical intensive care unit. Transfus Med Hemotherapy 44:85-92. https://doi.org/ $10.1159 / 000468946$

30. Grainger DJ, Wakefield L, Bethell HW, Farndale RW, Metcalfe JC (1995) Release and activation of platelet latent TGF- $\beta$ in blood clots during dissolution with plasmin. Nat Med 1:932-937. https://doi.org/10.1038/nm0995-932

31. Bowen T, Jenkins RH, Fraser DJ (2013) MicroRNAs, transforming growth factor beta-1, and tissue fibrosis. J Pathol 229:274-285. https://doi.org/10.1002/path.4119

32. Schuliga M (2015) The inflammatory actions of coagulant and fibrinolytic proteases in disease. In: Mediators Inflamm. https:// www.hindawi.com/journals/mi/2015/437695/. Accessed 25 Jun 2020
33. Monroe DM, Hoffman M, Roberts HR (2002) Platelets and thrombin generation. Arterioscler Thromb Vasc Biol 22:1381-1389. https://doi.org/10.1161/01.atv.0000031340.68494.34

34. Tada T, Kanaji M, Kobayashi S (1994) Induction of communicating hydrocephalus in mice by intrathecal injection of human recombinant transforming growth factor-beta 1. J Neuroimmunol 50:153158. https://doi.org/10.1016/0165-5728(94)90041-8

35. Wyss-Coray T, Feng L, Masliah E et al (1995) Increased central nervous system production of extracellular matrix components and development of hydrocephalus in transgenic mice overexpressing transforming growth factor-beta 1. Am J Pathol 147:53-67

36. Cherian S, Thoresen M, Silver IA, Whitelaw A, Love S (2004) Transforming growth factor- $\beta \mathrm{s}$ in a rat model of neonatal posthaemorrhagic hydrocephalus. Neuropathol Appl Neurobiol 30:585-600. https://doi.org/10.1111/j.1365-2990.2004.00588.x

37. Aquilina K, Chakkarapani E, Thoresen M (2012) Early deterioration of cerebrospinal fluid dynamics in a neonatal piglet model of intraventricular hemorrhage and posthemorrhagic ventricular dilation: laboratory investigation. J Neurosurg Pediatr 10:529-537. https://doi.org/10.3171/2012.8.PEDS11386

38. Douglas-Escobar MV, Weiss MD (2013) Biomarkers of brain injury in the premature infant. Front Neurol 3. https://doi.org/10. 3389/fneur.2012.00185

39. Anatol M, Tim L, Margaret B et al (2014) Inhibition of transforming growth factor- $\beta$ attenuates brain injury and neurological deficits in a rat model of germinal matrix hemorrhage. Stroke 45:828-834. https://doi.org/10.1161/STROKEAHA.113.003754

Publisher's note Springer Nature remains neutral with regard to jurisdictional claims in published maps and institutional affiliations. 